\title{
Marketed surplus and milk marketing channels in Madhya Pradesh: Implica- tions for dairy farmers and traders
}

\author{
Aditi Agrawal and Raju R \\ Received: 06 January 2021 / Accepted: 17 February 2021 / Published online: 07 June 2021 \\ (c) Indian Dairy Association (India) 2021
}

\begin{abstract}
The study has addressed the issue associated with the alternative milk market chains and their implications on dairy farmers and traders. The study was conducted by collecting data from 80 producer households along with 28 market intermediaries involved in the marketing of milk from producers to end consumers in the study area. The study revealed that the overall marketed surplus of milk in the study area was found to be 74.77 per cent and was highest for large category households. Out of the total marketed surplus, 79.78 per cent of milk was disposed of through unorganized sector while only 20.22 per cent was available to organized sector in the study area. Among the existing milk marketing agencies in the area, milk vendors were dominating and collecting a major share of raw milk from the producers. Among the various milk marketing channels involving intermediaries, producer's share in consumer's rupees as well as marketing efficiency, was found to be highest in channel-d! (producer-halwai-consumer) in the study area. The findings from the study suggest that producers should dispose of their milk through those channels in which minimum marketing agencies were involved and traditional milk sector should be addressed in a constructive manner due to their dominance in milk marketing in the state.
\end{abstract}

Division of Agricultural Economics, ICAR-Indian Agricultural Research Institute, New Delhi - 110012, India

Aditi Agrawal ( $\square)$

Division of Agricultural Economics, ICAR-Indian Agricultural Research Institute, New Delhi - 110 012, India

Email: aditiagrawalsp@gmail.com
Keywords: Milk, Marketing agencies, Marketed surplus, Marketing efficiency

\section{Introduction}

Milk production in India has been increased three-fold between 1970 and 2019 which represents a sustained growth for meeting the growing demand of milk, but the dominance of traditional marketing channels has not been affected. Marketing is as critical to better performance in dairying as dairy farming itself. The importance of marketing farm produces has been realized long ago. This fact has been supported by the report of the National Commission on Agriculture, 1976 which emphasized that it is not enough to produce a crop or an animal product but it must be satisfactorily marketed. Out of the total milk production in India, 48 per cent is consumed at the producer level while 52 per cent is available for non-producers. Out of this total marketed surplus, 40 per cent of the milk sold is handled by the organized sector while the remaining 60 per cent by the unorganized sector (GOI, 2018).

Madhya Pradesh is $3^{\text {rd }}$ highest milk producing state (15.91 million tonnes) and ranks sixth in terms of per capita milk availability (538 g/cap/day) in India (NDDB, 2019). Milch animals are owned by the farmers who are located in a widely dispersed rural area and this large group of scattered farmers cannot be covered by the milk co-operative societies. Consequently, traditional milk marketing is dominating in the state. A study carried out by Sharma (2012) in Malwa region of Madhya Pradesh reported that 80-85 per cent of the marketed surplus is disposed of through traditional milk marketing channels, while only $15-20$ per cent is available to milk co-operatives in the area. These traditional and informal milk marketing chains often provide the main outlet for smallholder dairy producers and major source of fresh milk supply for consumers. They have been playing a pivotal role in linking growing demand among consumers with increased production from producers. The emergence of modern milk marketing chains is posing stiff competition for the existence of traditional milk market agents. However, the basic structure of milk production and marketing is not likely to change significantly in the near future and therefore, the dominance of traditional milk market 
chains will continue to persist in spite of the rapid growth of the organized and formal milk marketing chains.

Keeping the above points into consideration, the present study was undertaken to determine the marketed surplus of milk and analyze the marketing efficiency of various milk marketing channels for disposal of milk in study area.

\section{Material and Methods}

\section{Study area}

Madhya Pradesh consists of 11 Agro-Climatic Zones, from which two zones, namely, Malwa (Western) and Kymore (Eastern) were purposively selected. Malwa region being very much advance in livestock farming, accounted for about 22.18 per cent of the bovine population of the state. It is having the largest crossbred ( 37.05 per cent) and buffalo (25.83 per cent) population of the state and contributes the highest share (23.18 per cent) to the states total milk production (GOI, 2019). On the other hand, the Kymore plateau is considered to be one of the backward regions in livestock farming in the state, contributing 8.17 per cent to the state's milk production. This region has the largest population of indigenous cattle (15.25 per cent) but their productivity was very low ( 0.5 to 1.5 litres/animal/day).

\section{Sampling}

Multi-stage random sampling technique was adopted for the selection of districts, tehsils and villages. One district from each zone i.e., Dewas district from Malwa plateau and Panna district from Kymore plateau was selected randomly. One block from each district i.e., Khategaon block from Dewas district and Powai block from Panna district was randomly selected. From each block, two villages were randomly selected i.e., Kharda and Jiyagaon from khategaon while Bolai and Krishngarh from Powai. A predetermined sample of 80 milk producers, 10 milk vendors, 08 creameries, 05 halwais and 05 contractors were drawn randomly from the four villages.

\section{Selection of sample households}

A predetermined sample of 80 producer households was drawn randomly from all four villages. The selected households were post stratified into three categories based on milch animals viz., small (1.39-2.94 SAU), medium (2.95-4.70 SAU) and large (4.718.95 SAU) using Cumulative Square Root Frequency Method. Thus, the 80 households were distributed as 42 (52.50 per cent) in small herd size category, 26 (32.50 per cent) in medium and 12 (15 per cent) in large herd size category.

\section{Selection of milk marketing agencies}

Both the organized (modern) and unorganized (traditional) sectors of milk marketing were functioning in the districts. The description of the milk marketing agencies is given below:

\section{Milk vendors}

A milk vendor collects milk from milk producers and sells it to the consumers or to the other milk marketing functionaries.

\section{Creameries}

They collect milk from milk producers and sell it to the direct consumer in the form of raw milk or milk products.

\section{Contractors}

Milk contractor collects milk from milk vendor or other milk marketing agencies and sells it to the customers as per the demand.

\section{Halwais}

Halwai collects the milk from either producer directly or from different milk marketing agencies and sell it to the consumers in the form of milk or milk products like sweets.

The information was collected by personal interview from the above intermediaries on average quantities of milk purchased by them each day from the producers at various prices and sold either to the consumers or the contractors at different prices. Information was also collected on various aspects like investment on vehicle and types of equipments along with their expected life, fuel cost, labour cost and other miscellaneous cost, time spent in milk collection, distance travelled by them per day for milk collection and distribution etc.

\section{Analytical framework}

\section{Marketed surplus}

Marketed surplus is that part of the produce which is brought to the market for sale by the producer after retaining some quantity for his family consumption. The total milk produced by all the milch animals in the sampled unit was reckoned as milk production for that unit. The quantity of milk which is retained by the sampled unit for consumption as liquid milk or by conversion into different products has been taken as its total consumption, while the quantity of milk and milk products which is left over after meeting his consumption need will be available for marketing which is called marketed surplus of that sampled unit.

Marketed surplus of milk $=$ Total milk production - Total milk consumption 


\section{Disposal pattern of marketed surplus of milk}

The disposal of milk consists of the retention of liquid milk and conversion of milk into different milk products at the household level and the remaining part out of total milk production that is available for sale as liquid milk in the market.

The information regarding the quantity of milk consumed at home and the agency to whom the milk was sold, i.e., co-operative societies, private dairies, milk vendor, processor or directly to the consumer along with average price realized were collected and analyzed for different categories of households.

\section{Marketing efficiency of milk marketing channel}

It involves the mapping of various agencies involved in the production and consumption of milk and milk products in the study area. They can be categorized into direct and indirect channels. In direct channel, milk and milk products are directly sold to consumers, while indirect channel involves a number of intermediaries to make available milk and milk products to the end consumers.

\section{Cost components of milk marketing agencies}

The expenditure on various items was classified according to their fixed and variable expenditure.

Fixed cost: Fixed costs include interest on fixed capital and depreciation on vehicles and equipments. Cost of durable assets (depreciation) can be accounted for by using the Capital Recovery Cost (CRC) Method.

The CRC method is defined as the annual payment that will repay the cost of fixed input over the useful life of input and provide an economic rate of return on investment. The interest on fixed capital does not need to be accounted separately when CRC approach is followed.

The formula for estimation of CRC is:

$$
\mathrm{R}=\mathrm{Z} \frac{\left[\left\{(1+\mathrm{r})^{\mathrm{n}} \mathrm{xr}\right\}\right]}{\left\{(1+\mathrm{r})^{\mathrm{n}}-1\right\}}
$$

Where,

$\mathrm{R}=$ Capital recovery cost

$\mathrm{Z}=$ Initial value of the capital asset

$\mathrm{r}=$ Current interest rate

$\mathrm{n}=$ Useful life of the assets/animals

Variable cost: it consists of:

\section{Raw milk cost}

To estimate the raw milk cost, the quantity of raw milk purchased by each agency was multiplied by their prices paid.

\section{Fuel cost}

Fuel cost included expenses on petrol for the vehicle, wood and match box.

\section{Electricity cost}

Electricity was used for running electric equipments like fan, light, refrigerator, etc.

\section{Labour used in business}

Wage prevailing in the area was taken as labour cost and calculated by taking into consideration the time spent on different activities of milk marketing.

\section{Miscellaneous cost}

Miscellaneous cost included the cost of repair of equipments and vehicles, cost of gunny bags, cost of chemicals used for making milk products, cost of small glassware etc.

\section{Marketing efficiency}

For calculation of marketing efficiency, information on milk marketing channels, cost and returns of various marketing agencies, producers' share in consumer rupees and price spread was collected and analyzed using the method suggested by Acharya and Agrawal (2009).

\section{Price spread}

The economic efficiency of marketing system is generally measured in terms of the price spread of an agricultural commodity. The smaller the price spread; the greater will be the efficiency of a marketing system.

$$
\mathrm{P}_{\mathrm{S}}=\mathrm{P}_{\mathrm{C}}-\mathrm{P}_{\mathrm{F}}
$$

Where,

$$
\begin{gathered}
\mathrm{P}_{\mathrm{S}}=\text { Price Spread } \\
\mathrm{P}_{\mathrm{C}}=\text { Consumer's Price } \\
\mathrm{P}_{\mathrm{F}}=\text { Producer's Price } \\
\text { Producer's share in consumer's rupee }
\end{gathered}
$$

It is the price received by the farmers and expressed as a percentage of the price paid by the consumer.

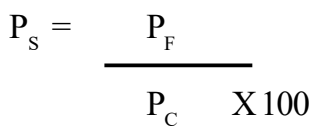


Where,

$\mathrm{P}_{\mathrm{S}}=$ Producer's share in consumer's rupee

$\mathrm{P}_{\mathrm{F}}=$ Producer's price

$\mathrm{P}_{\mathrm{C}}=$ Consumer's Price

\section{Marketing efficiency}

Marketing efficiency was calculated by using formula as given below.

$$
\mathrm{MME}=\frac{\mathrm{FP}}{(\mathrm{MC}+\mathrm{MM})}
$$

Where,

$$
\begin{aligned}
& \text { MME }=\text { Modified measure of marketing efficiency } \\
& \text { FP }=\text { Price received by the producer } \\
& \text { MC }=\text { Marketing Cost } \\
& M M=\text { Marketing margins }
\end{aligned}
$$

\section{Results and Discussion}

\section{Marketed surplus of milk}

The average production and marketed surplus of milk per day was worked out for different categories of households and are presented in the Table 1.
As evident from the Table 1 that the overall average milk production was 9.85 litres per day which varied from 5.73 litres in case of small category to 20.04 litres in case of large category households. A perusal at the table indicates that consumption had direct relation with the family size i.e., consumption was increasing with the increase in family size. The overall average marketed surplus was 7.36 litres per day which is highest for large category (16.33 litres/day) followed by medium category. The overall proportion of marketed surplus of milk to total milk was 74.77 per cent and was highest for large category households i.e., 81.50 per cent followed by medium (75.88 per cent) and small category households (66.65 per cent). Both in relative as well as in absolute terms, production and marketed surplus increased with the increase in the herd size implying positive relationship between production and marketed surplus of milk. These findings are similar to that reported by many authors (Yogi et al. 2007; Sharma, 2012; Meena and Tiwari, 2015).

\section{Disposal pattern of marketed surplus of milk}

It was observed that both organized and unorganized agencies were operational in the study area. The organized sector consists of milk co-operative societies while unorganized sector mainly comprises of milk vendors, creameries, halwais, consumers etc.

The study revealed that out of the total marketed surplus of milk

\begin{tabular}{|c|c|c|c|c|}
\hline Particulars & Small & Medium & Large & Overall \\
\hline Average milk production (litres/day) & 5.73 & 11.80 & 20.04 & 9.85 \\
\hline Family size (No.) & 6.43 & 6.72 & 7.01 & 6.62 \\
\hline Average milk consumption (litres/day) & 1.92 & 2.85 & 3.67 & 2.48 \\
\hline Marketed surplus as percent of total production & 66.65 & 75.88 & 81.50 & 74.77 \\
\hline
\end{tabular}
i.e., 589 litres, large proportion of milk was disposed of through the unorganized sector ( 79.78 per cent) while only 20.22 per cent was sold through organized sector. Among the various intermediaries present in unorganized sector, 34.18 per cent and

Table 1 Average milk production, consumption and marketed surplus of milk across the herd size category

Table 2. Disposal of milk to different milk marketing agencies across herd size category (Litres/day)

\begin{tabular}{llllll}
\hline Sl. No. & Milk marketing channels & Small & Medium & Large & Overall \\
\hline I & Unorganized sector & & & & \\
1 & Directly to consumers (C-I) & $10.95(6.83)$ & $18.20(7.82)$ & $10.28(5.24)$ & $39.43(6.69)$ \\
2 & Milk vendor (C-II) & $56.18(35.02)$ & $79.65(34.22)$ & $65.55(33.44)$ & $201.38(34.18)$ \\
3 & Milk vendor (C-III) & $30.17(18.81)$ & $40.37(17.34)$ & $31.67(16.16)$ & $102.21(17.35)$ \\
4 & Creamery (C-IV) & $25.14(15.67)$ & $32.41(13.92)$ & $47.66(24.32)$ & $105.21(17.86)$ \\
5 & Halwai(C-V) & $8.72(5.44)$ & $7.28(3.13)$ & $5.79(2.95)$ & $21.79(3.70)$ \\
& Total & $131.16(81.77)$ & $177.91(76.44)$ & $160.95(82.12)$ & $470.02(79.78)$ \\
II & Organized sector & & & \\
1 & Milk cooperative societies & $29.24(18.23)$ & $54.84(23.56)$ & $35.05(17.88)$ & $119.13(20.22)$ \\
& Overall Total & $160.40(100.00)$ & $232.75(100.00)$ & $196.00(100.00)$ & $589.15(100.00)$ \\
\hline
\end{tabular}

Figures in parentheses indicate percentage to the overall total 


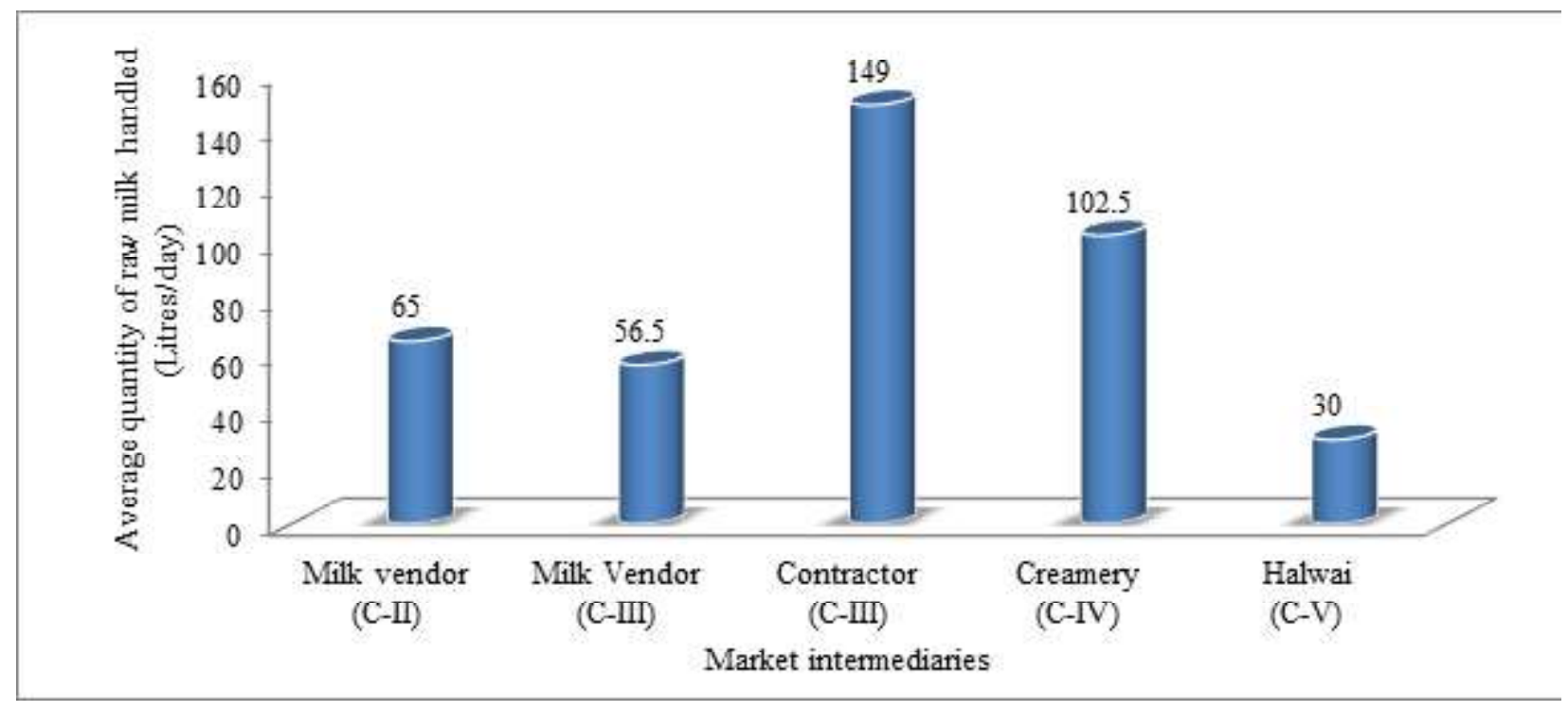

Fig. 1 Average quantity of raw milk handled by various market intermediaries

17.35 per cent of the milk was disposed off through milk vendor who directly sell milk to consumers and to the contractor, respectively. About 6.69 per cent of the total milk marketed by producers was disposed off directly to consumers of the same area. Thus, milk vendors were found to be the dominating agency in procuring milk from producers in the study area. These findings are in accordance with Sharma (2012) in Malwa zone of Madhya Pradesh. The co-operatives were getting their highest proportion of marketed surplus of milk from medium category households ( 23.56 per cent) in both relative and absolute terms followed by small category. The possible reason for channelizing higher proportion of milk by medium and small farmers towards cooperative societies may be due to better price, input supply like cattle feed, fodder and veterinary care etc. The requirement of halwais in the area was less and therefore mainly fulfilled by small and medium farmers.

\section{Marketing efficiency of different milk marketing channels}

An efficient marketing system is an effective agent of change and an important means of raising the income level of the producer farmers vis-a-vis level of consumer satisfaction. In the present study, a complete chain of traditional milk marketing has been studied right from the milk producers to the consumer as well as various intermediaries involved in marketing of milk in different channels in the study area. Traditional milk marketing in the present study refers to the informal sector, whereas the modern milk marketing is the concept referred to the formal sector.

\section{Milk marketing channels}

The marketing channels which were found to be active in the study area are:
1. Producer - Village Co-operative Societies - District Milk Union - Retailer-Consumer

\section{Producer - Milk Vendor - Consumer}

3. Producer - Milk Vendor - Contractor-Consumer

4. Producer - Creameries - Consumer

5. Producer - Halwai - Consumer

6. Producer - Consumer

In the study area, mainly six channels were found working. But, the investment pattern of intermediaries, cost and returns of marketing agencies and marketing efficiency was worked out only for the traditional milk marketing channels as they were having the dominant share in procuring milk sold by producers in the study area as confirmed by earlier study conducted by Sharma (2012) in Madhya Pradesh. Many other authors in different states also reported the same findings viz., (Singh, 2016; Singh, 2013; Yogi et al. 2007; Vedmurthy and Chauhan, 2005).

Channel-I: Producer-Consumer

Channel-II: Producer - Milk Vendor - Consumer

Channel-III: Producer - Milk Vendor - Contractor - Consumer

Channel-IV: Producer - Creameries - Consumer

Channel-V: Producer - Halwai - Consumer 


\section{Average quantity of raw milk handled}

Marketing agencies who are interviewed for data collection were also collecting milk from other villages besides the sample households in the study area.

On an average, creameries in channel-IV handled 102.5 litres/ day, milk vendor in channel-II handled 65 litres/day, milk vendor in channel-III handled 56.5 litres/day, halwais in channel-V handled 30 litres/day and contractor in channel-III handled the maximum amount of milk among all intermediaries i.e., 149 litres/ day.

\section{Investment pattern of market intermediaries}

Investment of any dairy business activities depends upon the scale of operation, initial or working capital, types of business (as milk vendor, milk contractors, creameries, halwais etc.), size of business, equipments used etc. Keeping these facts in view, marketing agencies decides their own investment pattern as per the scale of operation. Table 3 shows the average initial investment by the various marketing functionaries.

\section{Investment in the business of Vendor}

Milk vendors make different initial investments for starting the business on transporting vehicles and equipments like milk cans (aluminium and plastic cans), weighing balance, etc. In case of milk vendor in Channel-II, the overall initial average investment on vehicle and equipments was observed to be Rs. 54,750 and $^{1}$ 7,800 , respectively, while in case of milk vendor in Channel-III, it was Rs. 49,666.67 and Rs. 6,083.33 on vehicle and equipments, respectively. Similar findings were also reported by (Singh, 2016; Vedmurthy and Chauhan, 2005) in their studies.

\section{Investment in the business of Contractor}

This agency was observed with higher average initial investment and higher quantity of milk procurement from milk vendors. In case of vehicle, the initial investment was found to be Rs. 2,82,500 while equipment accounted for about Rs. 15,375.

Table 3 Average initial investments by marketing agencies (Rs. /Agency)

\begin{tabular}{llllll}
\hline Sl. No. & Particulars & \multicolumn{3}{c}{ Investment on } & Total \\
\cline { 3 - 5 } & & Building & Vehicle & Equipment & \\
\hline 1 & Milk vendor(Channel-II) & - & $54,750(87.95)$ & $7,800(12.05)$ & $62,550(100.00)$ \\
2 & Milk vendor(Channel-III) & - & $49,666.67(89.09)$ & $6,083.33(10.91)$ & $55,750(100.00)$ \\
3 & Contractor(Channel-III) & - & $2,82,500(94.84)$ & $15,375(5.16)$ & $2,97,875(100.00)$ \\
4 & Creameries(Channel-IV) & - & $52,650(55.32)$ & $42,525 *(44.68)$ & $95,175(100.00)$ \\
5 & Halwai(Channel-V) & $63,750(85.33)$ & $8,875(11.88)$ & $2,087.5(2.79)$ & $74,712.5(100.00)$ \\
\hline
\end{tabular}

Figures in parentheses indicate percentage to row total $*$ furniture and refrigerator included

Table 4 Costs incurred by different milk marketing agencies (Rs. /litres)

\begin{tabular}{|c|c|c|c|c|c|}
\hline Particulars & $\begin{array}{l}\text { Milk Vendor } \\
(\mathrm{C}-\mathrm{II})\end{array}$ & $\begin{array}{l}\text { Milk Vendor } \\
\text { (C-III) }\end{array}$ & $\begin{array}{l}\text { Contractor } \\
\text { (C-III) }\end{array}$ & $\begin{array}{l}\text { Creameries } \\
(\mathrm{C}-\mathrm{IV})\end{array}$ & $\begin{array}{l}\text { Halwai } \\
(\mathrm{C}-\mathrm{V})\end{array}$ \\
\hline & & \multicolumn{4}{|l|}{ Fixed cost } \\
\hline CRC on building & - & - & - & - & 0.70 \\
\hline CRC on equipment & 0.04 & 0.04 & 0.06 & 0.22 & 0.05 \\
\hline Total fixed cost & 0.12 & 0.11 & 0.25 & 0.29 & 0.80 \\
\hline Fuel cost & 2.22 & 1.53 & 3.10 & 2.85 & 2.54 \\
\hline Electricity cost & 0.00 & 0.00 & 0.00 & 0.19 & 0.14 \\
\hline Labor cost & 2.98 & 2.07 & 2.88 & 3.61 & 1.49 \\
\hline Miscellaneous cost & 0.03 & 0.03 & 0.03 & 0.04 & 0.04 \\
\hline Total variable cost & 42.15 & 36.70 & 44.92 & 43.94 & 43.84 \\
\hline Consumer's price ( ${ }^{1} /$ litre $)$ & 47.36 & 38.90 & 47.73 & 48.53 & 48.13 \\
\hline Margin or returns & 5.09 & 2.09 & 2.57 & 4.30 & 3.49 \\
\hline
\end{tabular}




\section{Investment in the business of Creameries}

Creameries collect raw milk from the milk producers and supply it to the end consumers. Out of total investment made by them, 55.32 per cent of it was made on vehicle while 44.68 per cent was incurred on equipments (Table 3 ). These results are in conformity with the similar study conducted by (Singh, 2013).

\section{Investment in the business of Halwais}

Halwais present in the study area used to collect milk from the producers and supply it either in raw form or in processed form to the consumers. On an average, they invest 85.33 per cent of their total investment on building while 11.88 per cent and 2.79 per cent was invested on vehicle and equipments.

\section{Cost and returns of milk marketing agencies}

Cost and returns depends on the types of marketing agencies involved in the marketing of milk. Table 4 indicates the cost and returns of various milk marketing agencies.

\section{Milk vendor}

Milk vendor in Channel-II handled on an average 65 litres of milk per day. They incurred total marketing cost of Rs. 5.34 per litre in channel-II. Out of the total marketing cost excluding milk cost, fixed and variable cost were observed to be 2.25 per cent and 97.75 per cent, respectively. They had spent total milk marketing cost including milk cost of Rs. 42.27 per litre and obtained returns of Rs. 5.09 per litre in channel-II (Table 4).

On the other hand, milk vendor in Channel-III handled incurred total marketing cost excluding milk cost to be of Rs. 3.74 per litres since they did not dispose-of milk directly to consumer. The share of variable cost was found to be highest ( 97.50 per cent). The returns to milk vendors in channel-III were found to be Rs. 2.09 per litre.

\section{Contractor}

They collect milk from milk vendor (Channel-III) and supply it to consumers. They incurred total marketing cost of Rs. 6.26 per litre of milk among which the variable cost has highest share i.e., 96.01 per cent. The margin of milk contractor was found to be ${ }^{1}$ 2.57 per litre in channel-III (Table 4).

\section{Creameries}

Almost all the creameries were running on rented shops in the study area. In channel-IV, they incurred total marketing cost of Rs. 6.98 per litre. Out of these, 4.15 per cent was worked out to be fixed cost while 95.85 per cent was variable cost. The returns of creameries were worked out to be Rs. 4.30 per litre (Table 4 ).

\section{Halwais}

Halwais had well established shops in the study area either on rent or owned. They incurred total marketing cost of Rs. 5.01 per litre of milk. Out of the total marketing cost, they incurred Rs. 0.80 per litre on fixed assets while variable cost was found to be Rs. 4.21 per litre. They had obtained returns of Rs. 3.49 per litre in channel-d!.

\section{Producer's share in consumer's rupee}

Table 5 indicates that in channel-I, producer was selling milk directly to the consumer so complete amount of consumer's price was received by the producers. Hence, producer's share in consumer's rupee was 100 per cent. In channel-II, producer's share was 77.96 per cent while milk vendor accounts for 22.04 per cent. In channel-III, the producer's share in consumer's rupee was lowest among all the channels i.e., 69.28 per cent. In channelIV, producer was getting 76.75 per cent of the price paid by the consumer while creameries accounts for 23.25 per cent. Producer's share was 82.34 per cent while halwai was having only 17.66 per cent of price paid by consumer in channel-d!. Hence, Producer's share in consumer's rupee was observed to be highest in case of channel-V (82.34 per cent) after the channel-I (100\%).

Table 5 Share of producer and various agencies in consumer's price in different milk marketing channels

\begin{tabular}{|c|c|c|c|c|c|}
\hline Agencies & Channel-I & Channel-II & $\begin{array}{l}\text { Various Milk } \\
\text { Channel-III }\end{array}$ & $\begin{array}{l}\text { Marketing } \\
\text { Channel-IV }\end{array}$ & $\begin{array}{l}\text { Channel } \\
\text { Channel-V }\end{array}$ \\
\hline Producer's share & $40.52(100.00)$ & $36.93(77.96)$ & $33.07(69.28)$ & $37.24(76.75)$ & $39.63(82.34)$ \\
\hline Milk vendor & & $10.44(22.04)$ & & & \\
\hline Milk vendor & & & $5.83(12.22)$ & & \\
\hline Contractor & & & $8.83(18.50)$ & & \\
\hline Creameries & & & & $11.28(23.25)$ & \\
\hline Halwai & & & & & $8.50(17.66)$ \\
\hline Consumer's price (Rs.) & $\begin{array}{l}40.52 \\
(100.00)\end{array}$ & $\begin{array}{l}47.36 \\
(100.00)\end{array}$ & $\begin{array}{l}47.73 \\
(100.00)\end{array}$ & $\begin{array}{l}48.53 \\
(100.00)\end{array}$ & $\begin{array}{l}48.13 \\
(100.00)\end{array}$ \\
\hline
\end{tabular}

Figures in parentheses indicate percentage of consumer's price (column total) 
Table 6 Marketing cost, marketing margin and price spread in different milk marketing channels

\begin{tabular}{llllll}
\hline Particulars & & & Marketing & Channel & \\
\cline { 2 - 6 } & Channel-I & Channel-II & Channel-III & Channel-IV & Channel-V \\
\hline Net reciept to producer & 40.52 & 36.93 & 33.07 & 37.24 & 39.63 \\
Marketing cost & - & 5.34 & 10.00 & 6.98 & 5.01 \\
Marketing margin & - & 5.09 & 4.66 & 4.30 & 3.49 \\
Consumer's price & 40.52 & 47.36 & 47.73 & 48.53 & 48.13 \\
Price spread & 0 & 10.44 & 14.66 & 11.28 & 8.50 \\
\hline
\end{tabular}

Table 7 Marketing efficiency of different milk marketing channels

\begin{tabular}{llll}
\hline Channels & $\begin{array}{l}\text { Marketing cost }+ \text { marketing } \\
\text { margin }\end{array}$ & $\begin{array}{l}\text { Price received by } \\
\text { producer }\end{array}$ & Marketing efficiency \\
\hline Channel-I & - & 40.52 & - \\
Channel-II & 10.44 & 36.93 & 3.54 \\
Channel-III & 14.66 & 33.07 & 2.25 \\
Channel-IV & 11.28 & 37.24 & 3.30 \\
Channel-V & 8.50 & 39.63 & 4.66 \\
\hline
\end{tabular}

\section{Price spread}

Table 6 reveals that the price spread was zero in channel-I as it was a direct channel (Producer-Consumer). Price spread was worked out to be lower in case of channel-V i.e., Rs. 8.50 in comparison to channel-a! (Rs. 10.44), channel-IV (Rs. 11.28) and channel-III (Rs. 14.68). Hence, channel-III is the least efficient channel in the study area. In channel- $\mathrm{V}$, the marketing margin was also observed to be less than other channels except for channel-I which is a direct channel. Net receipt to producer is also higher in case of channel-V (Rs. 39.63) as compared to other milk marketing channels (Table 6). Hence, it can be said that milk sold through channel-V (Producer-Halwai-Consumer) which has the smallest price spread was more efficient as compared to other channels in the study area. This is in conformity with the similar findings of many authors (Singh, 2016; Singh, 2013; Yogi et al. 2007; Vedmurthy and Chauhan, 2005).

\section{Marketing efficiency}

Marketing efficiency is essentially the degree of market performance. It can be harnessed to improve the quality of the masses by raising the income level of the farmers as well as consumers satisfaction.

Table 7 revealed that channel-V (4.66) is more efficient than channel-II (3.54) followed by channel-IV (3.30) and channel-III (2.25), respectively. These findings are in agreement with the findings of other authors (Yogi et al. 2007; Vedamurthy and Chauhan, 2005) which indicates that the channels with fewer intermediaries were more efficient.

The marketing efficiency was found to be consistent in the present study in case of channel-V. Halwais paid higher price to the producers in comparison to other market agencies along with their lowest marketing cost and margin among all the agencies. Channel-II and channel-c! are efficient as compared to channelIII in the study area as they also provide better prices to producer as well as have lower marketing cost as compared to channel-II. In case of channel-III, two agencies were involved i.e. milk vendor and contractor, who collects milk from the producers and supply it to the end consumers. Because of more intermediaries, this channel showed less efficiency as they had higher margins and higher costs of marketing. In addition to this, they paid minimum price to the producers among all the agencies and therefore are less efficient which is found to be consistent with the similar study conducted by (Singh, 2016; Singh 2013).

\section{Conclusions}

The current study indicates that marketed surplus of milk was found to be increasing with the increase in herd size and the traditional milk marketing channels were procuring the major proportion (75-80 per cent) of marketed surplus in the study area. The study suggests that the producers should dispose of their milk through those channels in which minimum marketing agencies were involved which ensure better returns to them along with reasonable price to the consumers. Dominance of traditional milk markets emphasized that they need to be addressed in a constructive manner and the policies should be evolved which would allow informal players to improve their performance including quality control and their integration with the emerging modern milk supply chains in the state. The quality gap can be addressed to a large extent by popularizing training and certification programs for small-scale milk traders and processors. 


\section{Acknowledgements}

First author acknowledges financial assistance in form of institute fellowship during the period of M.Sc. research project. They are also grateful to the anonymous referee for their suggestions

\section{References}

Acharya SS, Agarwal NL (2009) Agricultural marketing in India (Fourth Edition). Oxford and IBH Publishing Co. Pvt. Ltd. New Delhi

GOI (1976) Report on the national commission on agriculture-Part f!. Ministry of agriculture and irrigation. New Delhi

GOI (2018) Basic animal husbandry \& fisheries statistics. Annual report 2017-18. Ministry of agriculture and farmers welfare. New Delhi

GOI (2019) $20^{\text {th }}$ livestock census - 2019 all India report. Ministry of fisheries, animal husbandry and dairying. New Delhi

Meena GL, Tiwari B (2015) Marketed surplus, consumption and disposal pattern of milk in Banswara district of Rajasthan. Asian J Animal Sci 10: 193-197
NDDB (2019) Annual report of national dairy development board. Anand, Gujarat, retrieved from http://www.nddb.coop

Sharma SK (2012) Economics of milk production and utilization pattern in Malwa plateau of Madhya Pradesh. M.V.Sc. Thesis submitted to ICAR-National Dairy Research Institute (Deemed University). Karnal, Haryana

Singh P (2016) Economic analysis of traditional milk supply chain in Ranchi district of Jharkhand. Indian J Eco Dev 12: 490-520

Singh V (2013) Economic Analysis of Traditional Milk Marketing Chain in Karnal District of Haryana. M.V.Sc. Thesis submitted to ICARNational Dairy Research Institute (Deemed University), Karnal, Haryana

Vedamurthy KB, Chauhan AK (2005) Economic analysis of milk marketing in Shimoga district of Karnataka. Indian J Agri Marketing 19: 39-48

Yogi RK, Chauhan AK, Sharma SP (2007) Economics of milk marketing in Jaipur district of Rajasthan. Indian J Dairy Sci 60: 307-312 